WAR DOCUMENTATION PROJECT

STU DY NO. I:

\title{
Guide to Captured German Documents
}

\author{
Prepared by \\ Gerhard L. Weinberg \\ and \\ the WDP staff \\ under the direction of \\ Fritz T. EPSTEIN
}

Prepared under contract AF 18 (600-1) with

THE BUREAU OF APPLIED SOCIAL RESEARCH

COLUMBIA UNIVERSITY 